CORRECTION

\title{
Correction to: Microfluidic deep mutational scanning of the human executioner caspases reveals differences in structure and regulation
}

Hridindu Roychowdhury and Philip A. Romero (D)

(c) The Author(s) 2022

Cell Death Discovery (2022)8:71 ; https://doi.org/10.1038/s41420-022-00873-1

Correction to: Cell Death Discovery https://doi.org/10.1038/s41420-

021-00799-0, published online 10 January 2022

The original version of this article unfortunately contained an error in an author name. Hridindu Roychowdhury was incorrectly spelled as "Roychowdury". The correct spelling is "Roychowdhury". The original article has been corrected.

\begin{abstract}
(C) Open Access This article is licensed under a Creative Commons Attribution 4.0 International License, which permits use, sharing, adaptation, distribution and reproduction in any medium or format, as long as you give appropriate credit to the original author(s) and the source, provide a link to the Creative Commons license, and indicate if changes were made. The images or other third party material in this article are included in the article's Creative Commons license, unless indicated otherwise in a credit line to the material. If material is not included in the article's Creative Commons license and your intended use is not permitted by statutory regulation or exceeds the permitted use, you will need to obtain permission directly from the copyright holder. To view a copy of this license, visit http://creativecommons. org/licenses/by/4.0/.
\end{abstract}

(c) The Author(s) 2022 